\title{
Pemberian Obat Massal Pencegah Filariasis di Desa Mbilur Pangadu, Kabupaten Sumba Tengah
}

\author{
Mass Drug Administration in the Village of Mbilur Pangadu, Central Sumba Regency
}

\author{
Varry Lobo,* Anderias Karniawan Bulu, dan Monika Noshirma \\ Loka Penelitian dan Pengembangan Kesehatan Waikabubak, Badan Penelitian dan Pengembangan \\ Kesehatan, Kementerian Kesehatan RI, Jalan Basuki Rahmat Km 5 Puu Weri, Waikabubak, Nusa Tenggara \\ Timur, Indonesia \\ *Korespondensi Penulis : varrylobo@ymail.com
}

Submitted: 17-07-2018; Revised: 13-09-2018; Accepted: 17-09-2018

DOI: https://doi.org/10.22435/mpk.v28i3.530

\begin{abstract}
Abstrak
Program filariasis di Indonesia dilakukan melalui dua strategi utama, yaitu memutuskan rantai penularan dengan pemberian obat massal di daerah endemis dan penatalaksanaan kasus klinis. Tujuan penelitian ini adalah untuk menilai pelaksanaan pemberian obat massal pencegah filariasis di Desa Mbilur Pangadu Kabupaten Sumba Tengah. Pemberian obat massal di Sumba Tengah adalah program yang pertama kali dilakukan dan belum pernah dievaluasi. Penelitian dilakukan dengan metode survei deskriptif pada seluruh penduduk Desa Mbilur Pangadu yang berumur $\geq 13$ tahun. Hasil penelitian menunjukkan bahwa sebagian besar responden yang tidak menerima obat berada pada semua kelompok umur $(>50 \%)$, berjenis kelamin laki-laki $(64,7 \%)$, pengetahuan kurang tentang filariasis $(85,8 \%)$ dan jarak pos pengobatan sulit dijangkau $(65,4 \%)$. Sebagian besar responden dengan pengetahuan tinggi maupun rendah tidak menerima obat $(>50 \%)$, namun mereka menerima program dengan baik. Keaktifan petugas kesehatan sangat berdampak terhadap penerimaan obat yaitu 95,6\%. Cara pendistribusian dan efek samping pengobatan tidak berdampak pada perilaku minum obat. Pedoman pelaksanaan pengobatan massal harus diketahui dan bisa dilaksanakan oleh seluruh petugas kesehatan agar mencapai terget yang diharapkan.
\end{abstract}

Kata kunci: pengobatan massal; pencegahan; filariasis

\begin{abstract}
Filariasis program in Indonesia is carried out through two main strategies, namely breaking the chain of transmission with mass drug administration in endemic areas and clinical case management. This research was aimed to assess the implementation of administration of filariasis preventive drugs in Mbilur Pangadu village, Central Sumba Regency. Mass drug administration in Central Sumba is the first program that has been carried out and has not been evaluated yet. The study was conducted with a descriptive survey method of Mbilur Pangadu Village population aged $\geq 13$ years. The results showed that the majority of respondents who did not receive the drug were in all age groups (> 50\%), sex male (64.7\%), lack of knowledge about filariasis (85.8\%) and distance of treatment posts difficult to reach (65.4\%). Most respondents with high or low knowledge did not receive drugs (>50\%), but they received the program well. Health activities have an impact of drug acceptance, which is $95.6 \%$. The method of distribution and side effects of treatment does not affect the behavior of taking medication. Guidelines for the implementation of mass treatment must be known and can be carried out by all health workers to achieve the expected target..
\end{abstract}

Keywords: mass treatment; prevention; filariasis 


\section{PENDAHULUAN}

Filariasis adalah penyakit tular vektor berbahaya yang menyerang saluran getah bening yang disebabkan oleh cacing Wucheraria bancrofti, Brugia malayi dan Brugia timori sehingga mengakibatkan kecacatan. ${ }^{1}$ Filariasis menjadi salah satu penyakit yang diprioritaskan untuk dieliminasi dan Wold Health Organization (WHO) telah mendeklarasikan "The Global Goal of Elimination of Lymphatic Filariasis as a Public Health Problem by the Year 2020."2

Kasus klinis filariasis di Indonesia dari tahun 2012 sampai dengan tahun 2014 mengalami peningkatan, tahun 2012 terdapat 11.903 kasus, tahun 2013 terdapat 12.714 kasus dan tahun 2014 terdapat 14.932 kasus. $^{3}$ Prevalensi mikrofilaria di Indonesia berkisar dari 1\% hingga 38,57\%, dimana prevalensi mikrofilaria di Maluku, Papua, Irian Jaya Barat, Nusa Tenggara Timur (NTT), dan Maluku Utara umumnya lebih tinggi dari pulau lainnya di Indonesia. ${ }^{4}$

Jumlah kasus filariasis di NTT mengalami peningkatan yaitu tahun 2012 terdapat 1.730 kasus, tahun 2013 menjadi 2.203 kasus, tahun 2014 meningkat lagi menjadi 3.175 kasus dan turun pada tahun 2015 menjadi 2.864 kasus. ${ }^{3}$ Kabupaten Sumba Tengah merupakan daerah endemis filariasis dimana Brugiya timori merupakan cacing penyebab filariasis dengan mikrofilaria rate (Mf rate) sebesar 3,44\%. Angka kejadian klinis kronis filariasis juga tinggi, yaitu pada tahun 2011 terdapat 15 kasus, tahun 2012 terdapat 44 kasus dan meningkat pada tahun 2013 menjadi 122 kasus. Desa Mbilur Pangadu merupakan wilayah kerja Puskesmas Lendi Wacu di Kabupaten Sumba Tengah dengan angka $M$ f rate sebesar $1 \%{ }^{4}$

Eliminasi filariasis untuk memutuskan rantai penularan dilakukan dengan Pemberian Obat Pencegahan secara Massal (POPM) filariasis di daerah kabupaten endemis. Pelaksanaan POPM filariasis dilakukan sekali setahun selama minimal lima tahun di daerah kabupaten endemis filariasis yaitu daerah dengan $M f$ rate $>1 \%$ dengan unit pelaksananya adalah kabupaten/kota. POMP filariasis bertujuan untuk mematikan semua mikrofilaria yang ada di dalam darah setiap penduduk dalam waktu bersamaan sehingga memutus rantai penularannya. ${ }^{5}$ Pelaksanaan POPM filariasis telah dilaksanakan namun beberapa kabupaten belum mencapai target nasional. Penelitian yang dilakukan di Kabupaten Sumba Barat Daya menunjukkan cakupan POPM filariasis pada periode pertama dan kedua sangat rendah dari target cakupan $\mathrm{WHO}(\geq 85 \%)$, cakupan berdasarkan penduduk sasaran pada tahun 2012 adalah 2,51\% dan menurun pada tahun 2013 menjadi $1,35 \%$. Rendahnya cakupan POPM filariasis menunjukkan rendahnya keberhasilan eliminasi filariasis. ${ }^{2}$

Pelaksanaan POPM filariasis periode pertama di Kabupaten Sumba Tengah baru dilakukan pada tahun 2014, dimana sebelumnya hanyabersifat selektifpada desa yang terdapatkasus filariasis. Keberhasilan POPM filariasis periode awal akan berdampak pada periode pengobatan selanjutnya sehingga dilakukan penelitian yang bertujuan untuk menilai pelaksanaan POPM filariasis periode awal dan permasalahannya.

\section{METODE}

Penelitian dilakukan di Desa Mbilur Pangadu, Kabupaten Sumba Tengah yang merupakan daerah endemis filariasis yang mana sebelum pengobatan massal telah dilakukan pengobatan selektif. Penelitian dilakukan pada tahun 2015 selama delapan bulan. Metode penelitian adalah survei deskriptif. Sampel penelitian dipilih secara non probability sampling dengan teknik total sampling, yaitu seluruh penduduk sasaran pengobatan berumur $\geq 13$ tahun.

Data diambil dari 394 responden menggunakan kuesioner terstruktur yang berisi pertanyaan tertutup yang telah dilakukan uji validitas dan reliabilitas terhadap 30 responden di Desa Ngadu Olu Kabupaten Sumba Tengah. Uji validitas menggunakan Parson Product Moment, dikatakan valid jika $\mathrm{r}$ hitung $>\mathrm{r}$ tabel, dengan tingkat kemaknaan 5\%. Uji reliabilitas menggunakan Alpha crombach yaitu menganalisis reliabilitas instrumen dari satu kali pengukuran, dikatakan reliabel jika nilai Alpha crombach $>0,6 .{ }^{6}$

Data dikumpulkan menggunakan metode survei secara door to door. Data hasil wawancara dilakukan pengoreksian data kemudian diberikan pengkodean pada tiap data yang termasuk dalam kategori yang sama. Pada variabel sikap, pengetahuan, dan peran petugas kesehatan akan dilakukan pemberian skor sesuai dengan skala pengukurannya.

Pengukuran pengetahuan menggunakan skala Guttman, dilakukan berdasarkan jawaban pertanyaan yang diberikan responden. Jumlah pertanyaan sebanyak tujuh pertanyaan. Bila jawaban responden benar akan diberi nilai 1, jika jawaban salah diberi nilai 0 . Tingkat pengetahuan dibedakan menjadi dua yaitu, pengetahuan baik dan kurang.

Pengukuran variabel sikap menggunakan skala Litker summated ratings dengan delapan pertanyaan. Pilihan jawaban dibedakan dalam lima 
tingkatan yaitu sangat setuju, setuju, kurang setuju, tidak setuju, dan sangat tidak setuju. Variabel sikap ini dikelompokkan menjadi dua yaitu sikap baik dan kurang.

Pengukuran variabel peran petugas kesehatan menggunakan skala Guttman, dilakukan berdasarkan jawaban pertanyaan yang diberikan responden. Jumlah pertanyaan sebanyak 10 pertanyaan. Bila jawaban responden 'Ya' akan diberi nilai 1, jika jawaban 'Tidak' diberi nilai 0 . Variabel peran petugas kesehatan dalam penelitian ini dibedakan menjadi dua yaitu, berperan dan tidak berperan.

Hasil pengkodean, data dimasukkan ke dalam komputer melalui program microsoft excel kemudian disajikan dalam bentuk distribusi frekuensi dengan narasi.

Etik penelitian diperoleh dari Komisi Etik Penelitian Kesehatan, Badan Litbangkes, Kemenkes RI (No. LB.02.01/5.2/KE.035/2015 Tanggal 15 Januari 2015).

\section{HASIL}

\section{Karakteristik Responden}

Pada Tabel 1, sebagian besar responden yang tidak menerima obat adalah kelompok umur dewasa namun hal ini tidak jauh berbeda dengan kelompok umur remaja maupun lansia. Berdasarkan jenis kelamin, laki-laki paling banyak tidak menerima obat. Responden dengan tingkat pendidikan tinggi maupun rendah hampir sama banyaknya tidak menerima obat, sedangkan responden dengan pengetahuan kurang baik lebih banyak tidak menerima obat. Hampir seluruh responden memiliki sikap yang baik terhadap pengobatan massal, namun dalam hal penerimaan obat hampir sama banyaknya responden yang tidak menerima obat.

Sebagian besar responden memiliki pengetahuan yang kurang baik, hal ini dapat dilihat pada Tabel 2 yaitu hampir seluruh responden tidak mengetahui penyebab, cara penularan, cara pencegahan, cara minum obat, jenis obat, dan aturan minum obat filariasis. Sedangkan hanya dua pertiga responden yang mengetahui tanda dan gejala filariasis.

\section{Pelayanan Kesehatan}

Pada Tabel 3, petugas yang berperan aktif hampir seluruh respondennya menerima obat yang dibagikan. Jarak rumah menuju pos pengobatan yang sulit dijangkau menyebabkan lebih dari sebagian responden tidak menerima obat yang dibagikan.

Sebagian besar responden mengatakan bahwa petugas kesehatan kurang berperan aktif dalam pelaksanaan POMP filariasis baik dalam memberikan penjelasan tentang penyakit filariasis, tanda dan gejala, cara penularan, cara pencegahan, pengobatan massal, keuntungan minum obat, aturan minum obat, dan efek samping pengobatan serta memberikan secara langsung obat filariasis dan meminta untuk minum depan petugas. Hal ini disajikan pada Tabel 4.

Pendistribusian obat sebagian besar dilakukan selain rumah ke rumah / melalui pos pengobatan. Hampir seluruh responden meminum obat baik didistribusikan dengan cara rumah kerumah maupun pendistribusian selain rumah ke rumah/melalui pos pengobatan. Responden yang menyatakan pernah merasakan efek dan tidak ada efek pada pengobatan selektif sebelumnya, hampir seluruhnya meminum obat yang dibagikan pada periode pertama POPM filariasis. Efek yang dimaksud adalah demam, pusing, sakit kepala, mual, muntah, penurunan nafsu makan, sakit otot, sakit sendi dan sesak nafas. Hal ini dapat dilihat pada Tabel 5.

Tabel 1. Karakteristik Responden pada Pelaksanaan POPM Filariasis di Desa Mbilur Pangadu

\begin{tabular}{|c|c|c|c|c|c|c|c|}
\hline \multirow{2}{*}{\multicolumn{2}{|c|}{ Variabel }} & \multicolumn{6}{|c|}{ Distribusi Obat } \\
\hline & & \multicolumn{2}{|c|}{ Terima Obat } & \multicolumn{2}{|c|}{ Tidak Terima Obat } & \multicolumn{2}{|c|}{ Total $(n=394)$} \\
\hline & & $\mathbf{n}$ & $\%$ & $\mathbf{n}$ & $\%$ & $\mathbf{n}$ & $\%$ \\
\hline \multirow[t]{3}{*}{ Umur } & Remaja & 48 & 41,7 & 67 & 58,3 & 115 & 29,2 \\
\hline & Dewasa & 67 & 40,4 & 99 & 59,6 & 166 & 42,1 \\
\hline & Lansia & 53 & 46,9 & 60 & 53,1 & 113 & 28,7 \\
\hline \multirow[t]{2}{*}{ Jenis kelamin } & Laki-laki & 66 & 35,3 & 121 & 64,7 & 187 & 47,5 \\
\hline & Perempuan & 102 & 49,3 & 105 & 50,7 & 207 & 52,5 \\
\hline \multirow[t]{2}{*}{ Tingkat pendidikan } & Rendah & 131 & 42,4 & 178 & 57,6 & 309 & 78,4 \\
\hline & Tinggi & 37 & 43,5 & 48 & 56,5 & 85 & 21,6 \\
\hline \multirow[t]{2}{*}{ Pengetahuan } & Baik & 138 & 75,8 & 44 & 24,2 & 182 & 46,2 \\
\hline & Kurang Baik & 30 & 14,2 & 182 & 85,8 & 212 & 53,8 \\
\hline \multirow[t]{2}{*}{ Sikap } & Baik & 167 & 42,6 & 225 & 57,4 & 392 & 99,5 \\
\hline & Kurang Baik & 1 & 50 & 1 & 50 & 2 & 0,5 \\
\hline
\end{tabular}


Tabel 2. Pengetahuan Responden tentang Filariasis di Desa Mbilur Pangadu

\begin{tabular}{|c|c|c|}
\hline Pengetahuan & $\begin{array}{c}n \\
(n=394)\end{array}$ & $\%$ \\
\hline \multicolumn{3}{|l|}{ 1. Penyebab filariasis } \\
\hline Menginjak tempat terlarang & 6 & 1,5 \\
\hline Memakan makanan terlarang/ salah makan & 10 & 2,5 \\
\hline Disebabkan virus & 16 & 4,1 \\
\hline Cacing filarial & 38 & 9,6 \\
\hline Bakteri & 12 & 3,1 \\
\hline Tidak tahu & 293 & 74,4 \\
\hline Ular hijau & 19 & 4,8 \\
\hline \multicolumn{3}{|l|}{ 2. Cara penularan } \\
\hline Melalui air & 22 & 5,6 \\
\hline Melalui keringat & 3 & 0,8 \\
\hline Percikan ludah & 5 & 1,3 \\
\hline Gigitan nyamuk & 44 & 11,2 \\
\hline Makan bersama & 16 & 4 \\
\hline Tidak tahu & 298 & 75,6 \\
\hline Tidak sesuai & 6 & 1,5 \\
\hline \multicolumn{3}{|l|}{ 3. Tanda dan gejala penyakit filariasis } \\
\hline Adanya pembengkakan di bagian kaki, tangan dan kemaluan & 303 & 76,9 \\
\hline Kencing nanah & 1 & 0,3 \\
\hline Tidak tahu & 84 & 21,3 \\
\hline Tidak sesuai & 6 & 1,5 \\
\hline \multicolumn{3}{|l|}{ 4. Cara pencegahan } \\
\hline Menghindari gigitan nyamuk & 47 & 11,9 \\
\hline Makan makanan bergizi & 23 & 5,8 \\
\hline Memakai alas kaki saat berjalan & 78 & 19,8 \\
\hline Tidak tahu & 240 & 60,9 \\
\hline Tidak sesuai & 6 & 1,5 \\
\hline \multicolumn{3}{|l|}{ 5. Cara minum obat } \\
\hline Setiap bangun tidur pagi hari & 2 & 0,51 \\
\hline Siang hari & 1 & 0,25 \\
\hline Sesudah makan & 147 & 37,31 \\
\hline Sebelum makan & 8 & 2,03 \\
\hline Tidak tahu & 232 & 58,89 \\
\hline Tidak sesuai & 4 & 1,01 \\
\hline \multicolumn{3}{|l|}{ 6. Obat filariasis } \\
\hline DEC, Albendazole, Paracetamole & 92 & 23,35 \\
\hline Paracetamol & 4 & 1,02 \\
\hline Obat cacing biasa & 4 & 1,02 \\
\hline Tidak tahu & 285 & 72,33 \\
\hline Tidak sesuai & 9 & 2,28 \\
\hline \multicolumn{3}{|l|}{ 7. Aturan minum obat filariasis } \\
\hline 1 hari 1 tablet berturut turut selama 3 hari & 14 & 3,55 \\
\hline Diminum sekaligus 3 butir & 128 & 32,49 \\
\hline Tidak tahu & 245 & 62,18 \\
\hline Tidak sesuai & 7 & 1,78 \\
\hline
\end{tabular}


Tabel 3. Peran Petugas Kesehatan dan Jarak ke Tempat Pelaksanaan POPM Filariasis di Desa Mbilur Pangadu

\begin{tabular}{lcccc}
\hline & Variabel & & \multicolumn{3}{c}{ Distribusi obat } \\
\cline { 3 - 5 } & & $\begin{array}{c}\text { Terima obat } \\
\mathbf{n}(\mathbf{\%})\end{array}$ & $\begin{array}{c}\text { Tidak terima obat } \\
\mathbf{n}(\mathbf{\%})\end{array}$ & $\begin{array}{c}\text { Total } \\
(\mathbf{n}=\mathbf{3 9 4}) \mathbf{( \% )}\end{array}$ \\
\hline Peran petugas kesehatan & Berperan & $123(94,6)$ & $7(5,4)$ & $130(100)$ \\
& Kurang berperan & $45(17,1)$ & $219(82,9)$ & $264(100)$ \\
Jarak & Mudah dijangkau & $97(51,3)$ & $92(48,7)$ & $189(100)$ \\
& Sulit dijangkau & $71(34,6)$ & $134(65,4)$ & $205(100)$ \\
\hline
\end{tabular}

Tabel 4. Peran Petugas Kesehatan pada Pelaksanaan POPM Filariasis di Desa Mbilur Pangadu

\begin{tabular}{|c|c|c|c|c|c|}
\hline \multirow{2}{*}{ No } & \multirow{2}{*}{ Peran Petugas } & \multicolumn{2}{|c|}{ Ya } & \multicolumn{2}{|c|}{ Tidak } \\
\hline & & $\mathbf{n}$ & $\%$ & $\mathbf{n}$ & $\%$ \\
\hline 1 & Menjelaskan tentang penyakit filariasis & 59 & 14,97 & 335 & 85,03 \\
\hline 2 & Memberikan informasi tentang tanda dan gejala penyakit filariasis & 58 & 14,72 & 336 & 85,28 \\
\hline 3 & Memberikan informasi tentang cara penularan penyakit filariasis & 53 & 13,45 & 341 & 86,55 \\
\hline 4 & Menjelaskan cara pencegahan penyakit filariasis & 56 & 14,21 & 338 & 85,79 \\
\hline 5 & Menginformasikan pengobatan massal filariasis & 119 & 30,20 & 275 & 69,80 \\
\hline 6 & Menjelaskan keuntungan minum obat pencegah filariasis & 89 & 22,59 & 305 & 77,41 \\
\hline 7 & Memberikan informasi tentang aturan minum obat pencegah filariasis & 127 & 32,23 & 267 & 67,77 \\
\hline 8 & Menjelaskan efek samping pengobatan & 67 & 17.01 & 327 & 82,99 \\
\hline 9 & Memberikan secara langsung obat pencegah filariasis & 99 & 25,13 & 295 & 74,87 \\
\hline 10 & Meminta untuk minum obat di depan petugas & 8 & 2,03 & 386 & 97,97 \\
\hline
\end{tabular}

Tabel 5. Cara Pendistribusian dan Efek Samping Pengobatan pada Pelaksanaan POPM Filariasis di Desa Mbilur Pangadu

\begin{tabular}{|c|c|c|c|c|}
\hline & \multirow[b]{2}{*}{ Variabel } & \multicolumn{3}{|c|}{ Minum Obat } \\
\hline & & $\begin{array}{c}\text { Minum } \\
\text { n (\%) }\end{array}$ & $\begin{array}{c}\text { Tidak Minum } \\
\text { n (\%) }\end{array}$ & $\begin{array}{l}\text { Total } \\
\text { n (\%) }\end{array}$ \\
\hline \multirow{3}{*}{ Cara distribusi } & Rumah ke rumah & 9 & 1 & 10 \\
\hline & & (90) & (10) & $(100)$ \\
\hline & Selain rumah ke rumah* & 151 & 7 & 158 \\
\hline \multirow{3}{*}{ Efek samping pengobatan } & & $(95,6)$ & $(4,4)$ & $(100)$ \\
\hline & Ada & $50(100)$ & $0(0)$ & $50(100)$ \\
\hline & Tidak ada & $110(93,2)$ & $8(6,8)$ & $118(100)$ \\
\hline
\end{tabular}

* Pendistribusian melalui pos POMP filariasis dan dititipkan

\section{PEMBAHASAN}

Kabupaten Sumba Tengah adalah daerah endemis filariasis dan telah dilakukan pengobatan selektif filariasis pada desa yang memiliki kasus, salah satunya adalah Desa Mbilur Pangadu. Pelaksanaan pengobatan selektif di Kabupaten Sumba Tengah belum menunjukkan penurunan jumlah kasus dimana angka $M$ fRate 3,44\% ( $\geq 1 \%)$ sehingga dilakukan pengobatan massal filariasis pada seluruh desa di Kabupaten Sumba Tengah. ${ }^{5}$ Pengobatan massal filariasis baru dilakukan pada tahun 2014. Sukses tidaknya program eliminasi filariasis dapat dilihat bila cakupan POPM filariasis setiap desa/kelurahan atau wilayah setingkat desa adalah minimal sebesar $85 \%$ total penduduk wilayah tersebut. ${ }^{2}$ Hasil penelitian diketahui bahwa cakupan penerima obat filariasis hanya $42,6 \%$ dan cakupan minum obat $40,6 \%$, hal ini lebih rendah dari target capaian yaitu $85 \%$. Rendahnya cakupan ini dipengaruhi oleh banyak faktor baik dari internal maupun eksternal.

POPM filariasis di Desa Mbilur Pangadu belum menjangkau seluruh kelompok usia. Hal ini dikarenakan pembagian obat hanya dilakukan pada satu pos untuk seluruh masyarakat desa (kantor desa). Selain itu waktu pembagian obat dilakukan saat jam beraktifitas/kerja sehingga sebagian besar masyarakat yang beraktivitas pagi hingga sore hari tidak mengambil obat. Usia sekolah akan berada di sekolah hingga siang hari, 
begitu juga dengan pegawai yang bekerja hingga sore hari sehingga memperkecil kesempatan untuk pergi ke pos pengobatan. Berdasarkan panduan POPM filariasis pendistribusian obat dapat dilakukan dari rumah ke rumah, di pos pembagian obat, kelompok penduduk khusus (kelompok TNI, sekolah, pasien di rumah sakit, dll) dan tempat kumpul masyarakat (gereja, mesjid, pasar, terminal bis, dll). ${ }^{7}$

Waktu dan metode POPM filariasis yang tepat dapat menentukan luasan sasaran penerima obat. Lansia akan lebih tepat jika dibagikan dari rumah ke rumah, usia sekolah dibagikan di sekolah waktu kegiatan belajar, pegawai negeri/ swasta dibagikan saat sore sampai malam baik melalui pos pengobatan atau rumah ke rumah. Penelitian oleh Agustiantiningsih bahwa umur tidak menunjukkan hubungan yang bermakna terhadap praktik pencegahan filariasis $\mathrm{p}=0,476$ $(p>0,05)$, baik usia muda maupun tua memiliki perilaku yang kurang baik dalam pencegahan filariasis. $^{8}$ Berbeda dengan penelitian $\mathrm{Gaol}^{9}$ bahwa responden pada usia dewasa akan segera mencari pengobatan agar produktifitasnya tidak terganggu.

Laki-laki lebih banyak tidak menerima obat karena lebih banyak waktu berada di luar rumah. Laki-laki adalah tulang punggung keluarga yang bertugas untuk memenuhi kebutuhan hidup keluarga sehingga tidak memiliki kesempatan mengambil obat di pos pengbatan. Hal ini didukung dengan penelitian oleh Santoso ${ }^{10}$ bahwa perempuan lebih patuh dibanding laki-laki dalam pengobatan massal filariasis.

Tingkat pendidikan tidak berdampak pada responden menerima obat pencegah filariasis atau tidak. Sebagian besar responden dengan tingkat pendidikan rendah maupun tinggi tidak menerima obat pencegah filariasis. Hal ini sejalan dengan penelitian Santoso ${ }^{10}$ bahwa tidak ada perbedaan yang nyata antara pendidikan tinggi dan rendah terhadap kepatuhan masyarakat dalam pengobatan massal filariasis. Penelitian di Kabupaten Sumba Barat Daya menunjukkan sebagian besar responden berpendidikan rendah sehingga berdampak pada pengetahuan dan persentasi cakupan pengobatan massal filariasis rendah. ${ }^{11}$

Pengetahuan responden tentang filariasis masih kurang. Masyarakat masih meyakini bahwa filariasis disebabkan oleh gigitan ular hijau dan menginjak tempat terlarang. Gigitan ular hijau diyakini dapat menyebabkan pembengkakan yang permanen. Masyarakat juga meyakini adanya kutukan jika menginjak tempat sakral (pamali=sebutan bagi masyarakat Sumba) sehingga menimbulkan pembengkakan. Temuan ini sama dengan penelitian Anorital ${ }^{12}$ bahwa sebagian besar responden mengetahui penyebab filariasis karena menginjak daerah/ sungai terlarang. Sugiyanto ${ }^{13}$ menyatakan bahwa sebagian besar pengetahuan responden di daerah POPM filariasis termasuk kategori kurang dan tidak patuh minum obat. Ketidaktahuan responden tentang hal-hal mendasar dari penyakit filariasis menyebabkan mereka tidak tahu cara mencegah penularan. ${ }^{14}$ Kurangnya sosialisasi pelaksanaan POPM filariasis oleh petugas kesehatan merupakan salah satu penyebab rendahnya pengetahuan masyarakat sehingga kesadaran untuk mengambil obat menjadi tidak baik.

Meskipun pengetahuan rendah tapi responden memiliki sikap yang positif terhadap program POPM filariasis. Penelitian Ikawati ${ }^{15}$ juga menyatakan seluruh responden memiliki sikap yang positif terhadap pelaksanaan POPM filariasis Kecamatan Pekalongan Utara. Seluruh responden mendukung bahwa POMP filariasis adalah tanggung jawab pemerintah dan masyarakat serta sebagai upaya terhindar dari filariasis. Namun hal ini tidak berdampak pada perilaku dalam mengambil obat di pos pengobatan. Lebih dari setengah responden tidak menerima obat. Responden yang tidak memperoleh obat filariasis menyatakan bahwa mereka tidak mengetahuai adanya pembagian obat dan persediaan obat terbatas/habis. Hal ini sama dengan penelitian Veridiana ${ }^{14}$ bahwa sikap positif responden terhadap pencegahan dan pengobatan filariasis tidak diikuti dengan tindakan. Berbeda dengan penelitian Agustiantiningsih ${ }^{8}$ bahwa sikap yang baik dipengaruhi oleh pengetahuan yang baik sehingga akan mempengaruhi dalam praktik pencegahan filariasis, salah satunya dengan meminum obat filariasis yang dibagikan secara massal. Sikap dan tindakan nyata seringkali jauh berbeda hal ini karena tindakan nyata tidak hanya ditentukan oleh sikap semata namun juga ditentukan faktor eksternal lainnya.

Kader/petugas kesehatan yang ada belum seluruhnya melaksanakan tugas dan fungsinya, khususnya dalam penyuluhan dan kunjungan rumah. Kader berperan dalam meningkatkan pengetahuan masyarakat dan mendukung di pos pengobatan atau kunjungan untuk memastikan 
obat diminum. Jika petugas kesehatan aktif dalam mensosialisasiskan dan mendistribusikan POMP filariasis maka akan semakin banyak yang menerima obat. Penelitian di Kabupaten Batanghari Jambi menyatakan bahwa ketidaktahuan responden terhadap kegiatan POPM filariasis dan kurangnya sosialisasi, berhubungan secara bermakna dengan kesediaan minum obat. ${ }^{16}$

Pelaksanaan POPM filariasis di

Desa Mbilur Pangadu dilakukan bersamaan dengan program kelambu massal. Pelaksana "kelambunisasi" adalah orang yang sama untuk POPM filariasis. Hal ini juga yang menambah beban kerja kader filariasis sehingga menjadi tidak fokus. Kurangnya jumlah kader juga menjadi penghambat pelaksanaan POMP filariasis di Desa Mbilur Pangadu. Kader yang ada tidak sebanding dengan jumlah masyarakat yang dilayani. Kader merupakan ujung tombak dalam kelancaran POMP filariasis, dukungan kader sangat dibutuhkan untuk keberhasilan eliminasi filariasis. ${ }^{17}$

Jarak rumah responden menuju pos pembagian obat yang sulit dijangkau menjadi alasan responden tidak mengambil obat. Jarak rata-rata rumah responden ke pos pembagian obat filariasis adalah 1,7 KM dengan rata-rata waktu tempuh 39 menit dengan berjalan kaki. Menurut Hotnida $^{18}$ masyarakat akan berpikir ulang untuk berpergian jauh ke sarana pengobatan hanya untuk masalah kesehatan yang menurut mereka bukan merupakan penyakit berat. Selain itu, waktu tempuh yang singkat memiliki hubungan yang bermakna dengan kunjungan ke sarana pengobatan. ${ }^{19}$ Penelitian Rifqatussa' adah ${ }^{20}$ bahwa jauhnya jarak menyebabkan responden tidak berobat ke puskesmas dan tidak mengambil obat. Didukung penelitian Husin ${ }^{21}$ bahwa jarak berhubungan dengan perilaku pencarian pengobatan, jarak merupakan penghalang yang meningkatkan kecenderungan penundaan upaya seseorang atau masyarakat dalam mencari pelayanan kesehatan.

Pemberian obat filariasis tidak diimbangi dengan ketersediaan air minum sehingga masyarakat tidak diminta untuk minum di depan petugas. Obat yang diterima dibawa ke rumah untuk diminum, namun tidak diketahui apakah masyarakat minum obat atau tidak. Kunjungan rumah ke rumah pasca pengobatan tidak dilakukan sehingga tidak dapat memastikan obat yang dibagikan diminum atau tidak.
Responden yang pernah mengalami efek samping pada pengobatan selektif sebelumnya tetap meminum obat yang dibagikan. Hal ini dikarenakan efek samping yang dirasakan hanya berlangsung beberapa saat sehingga tidak menggangu aktivitas. Hasil ini berbeda dengan penelitian Sugiyanto ${ }^{13}$ di Kabupaten Bandung bahwa, takut reaksi/efek obat berkaitan dengan ketidakpatuhan minum obat filariasis, ketakutan disebabkan karena adanya kasus kematian setelah minum obat filariasis.

\section{KESIMPULAN}

Pelaksanaan POPM filariasis belum sesuai dengan pedoman. Fungsi kader filariasis belum dilaksanakan dengan baik, sehingga POPM filariasis tidak tersosialisasi kelapisan masyarakat. Pengetahuan masyarakat yang rendah tentang filariasis dan jarak pos pengobatan sulit dijangkau turut mendukung rendahnya cakupan pengobatan massal.

\section{SARAN}

Pelaksanaan POPM filariasis harus sesuai dengan pedoman pengobatan. Membentuk tim pelaksana eliminasi filariasis yang terlatih, sosialisasi sebelum pelaksanaan POPM filariasis, jumlah pos pengobatan yang sesuai dengan kepadatan penduduk, jarak dan sarana transportasi. Melakukan penyuluhan tentang penyakit filariasis maupun pelaksanaan pengobatan massal.

\section{UCAPAN TERIMA KASIH}

Penulis mengucapkan terima kasih kepada Kepala Loka Penelitian dan Pengembangan Kesehatan Waikabubak yang telah memberikan ijin serta arahannya dalam pelaksanaan penelitian ini. Terima kasih juga kepada Kepala Puskesmas Lendiwacu beserta petugas lapangan yang telah membantu dalam koordinasi kegiatan penelitian, dan semua penduduk Desa Mbilur Pangadu yang telah berpartisipasi dalam penelitian ini hingga selesai.

\section{DAFTAR PUSTAKA}

1. WHO. Limphatic filariasis a handbook for national elimination programmes. 2013.

2. Kementerian Kesehatan Republik Indonesia, Direktorat P2B2 DP. Rencana nasional program akselerasi eliminasi filariasis di Indonesia. 2010.

3. Kemenkes RI. Data dan informasi Tahun 2014 (Profil Kesehatan Indonesia). 2015. 
4. Dinas Kesehatan Kabupaten Sumba Tengah. Laporan penderita filariasis. Sumba Tengah: Dinas Kesehatan Kabupaten Sumba Tengah; 2013.

5. Direktorat Jenderal PP\&PL. Profil pengendalian penyakit dan penyehatan lingkungan. Jakarta: Direktorat Jenderal PP\&PL; 2013.

6. Sugiyono. Statistika untuk penelitian. Bandung: Alfabeta. 2013.

7. JUPT Pelatihan Tenaga Kesehatan Provinsi NTT. Modul pelatihan pengobatan massal filariasis limfatik dan penanganan berbagai kasus jangka panjang bagi petugas kesehatan. 2002.

8. Agustiantiningsih D. Praktik pencegahan filariasis. J Kesehat Masy. 2013;8(2):190-197.

9. Gaol TL. Pengaruh faktor sosiodemografi, sosioekonomi dan kebutuhan terhadap perilaku masyarakat dalam pencarian pengobatan di Kecamatan Medan Kota Tahun 2013. 2015.

10. Santoso. Kepatuhan terhadap pengobatan massal filariasis di Kabupaten Belitung Timur Tahun 2008. Bul Penelit Kesehat. 2010;38(4 Des):185-197.

11. Sopi IIPB, Wayan N, Adnyana D. Cakupan pengobatan massal filariasis di Kabupaten Sumba Barat Daya tahun 2011. J Ekol Kesehat. 2013;12(1):19-24.

12. Anorital A, Dewi R. Pengetahuan, Sikap dan Perilaku penderita filariasis malayi selama pelaksanaan pengobatan massal dii Kabupaten Tabalong Kalsel. Media Penelit dan Pengemb Kesehat. 2004;XIV(4):42-50.

13. Sugiyanto. Analisis faktor-faktor yang berhubungan dengan ketidakpatuhan minum obat filariasis pada kegiatan pengobatan massal tahun 2010 di wilayah kerja Puskesmas Soreang Kabupaten Bandung. 2-trik Tunastunas Ris Kesehat. 2012;II(1):1-8.
14. Veridiana NN, Sitti C, Ningsih. Pengetahuan, sikap dan perilaku masyarakat terhadap filariasis di Kabupaten Mamuju Utara,Sulawesi Barat. Bul Penelit Kesehat. 2015;43(1):47-54.

15. Ikawati B, Tri W. Pengetahuan, sikap dan praktik masyarakat Kelurahan Pabean, Kecamatan Pekalongan Utara, Kota Pekalongan tentang filariasis limfatik. Ekol Kesehat. 2010;9(4):1324-1332.

16. Ambarital LP, Yulian T, Hotnida SRIP, Kasnodiharjo. Perilaku masyarakat terkait penyakit kaki gajah dan program pengobatan massal di kecamatan pemayung kabupaten Batanghari Jambi. J Media Litbang Kesehat. 2014;24(4):191-198.

17. Astuti EP, Mara I, Tri W, Andri R. Analisis perilaku masyarakat terhadap kepatuhan minum obat filariasis di tiga desa Kecamatan Majalaya Kabupaten Bandung tahun 2013. 2014:199-208.

18. Hotnida S. Lasbudi A. Gambaran aksesibilitas sarana pelayanan kesehatan di Provinsi Bangka Belitung (Analisis data Riskesdas 2007). Bul Penelit Kesehat. 2010;26.

19. Nainggolan O. Dwi H, Lely I. Pengaruh akses ke fasilitas kesehatan terhadap kelengkapan imunisasi Baduta (Analisis Riskesdas 2013). Media Penelit dan Pengemb Kesehat. 2016;26(1):15-28.

20. Rifqatussa'adah. Perilaku minum obat pada penderita tuberkulosis (TB) paru di Kecamatan Johar Baru, Jakarta Pusat Tahun 2011. In: Prosiding Seminar Nasional Kesehatan. ; 2011.

21. Husin M. Analisis determinan perilaku masyarakat dalam pencarian pengobatan di Desa Sukarami Kecamatan Kikim Barat Kabupaten Lahat Tahun 2014. 2014. 